\title{
Evaluation of the wound healing potential of Aloe vera-based extract of Nerium oleander
}

\author{
Sevcan Gul Akgun, ${ }^{1}$ Sezgin Aydemir,${ }^{2}$ Naziye Ozkan, ${ }^{2}$ Meral Yuksel, ${ }^{3}$ Semra Sardas ${ }^{1}$ \\ ${ }^{1}$ Department of Pharmaceutical Toxicology, Faculty of Pharmacy, Marmara University, Istanbul, Turkey \\ 2Department of Pathology Laboratory Technicianship, Vocational School of Health Related Services, Marmara University, Istanbul, Turkey \\ ${ }^{3}$ Department of Medical Laboratory Technicianship, Vocational School of Health Related Services, Marmara University, Istanbul, Turkey
}

\begin{abstract}
OBJECTIVE: Nerium oleander (Apocynaceae) and Aloe vera (Liliaceae) are among the widely used herbal remedies for treating skin diseases and possess numerous activities such as antibacterial, antiviral, antifungal, and antioxidant. The aim of this study was to investigate the possible wound healing effect of Aloev era-based extract of the $N$. oleander leaf (NAE-8®) based on its antioxidant, anti-inflammatory, and DNA repair capacity along with histological changes and to compare them with the traditional silver sulfadiazine treatment (SSD).

METHODS: Twenty-four Wistar albino rats were randomly grouped as follows: i) control, ii) burn alone (burn), iii) burn with topical NAE- $8 \AA$ (burn+NAE- $8 \AA$ ) treatment, and iv) burn with topical $1 \%$ silver sulfadiazine (burn+SSD) treatment. All groups received their related topical application twice a day for 14 consecutive days. Upon completion of the experimental protocol, trunk blood and skin tissues were collected for measuring malondialdehyde (MDA), glutathione (GSH), myeloperoxidase (MPO), tumor necrosis factor alpha (TNF-a), interleukin-1 $\beta$ (IL-1 $\beta$ ), $\%$ DNA in the tail (\%DNAT) levels along with histological examinations.
\end{abstract}

RESULTS: Thermal injury-induced alterations in MDA, GSH, MPO, TNF-a, IL-1 $\beta$, and \%DNAT levels were significantly reversed by $N A E-8 \AA$ treatment. These ameliorative effects were also supported by histological findings.

CONCLUSION: Findings of the present study suggest that NAE- $8 \AA$ is a promising remedy for treating skin burn injury.

Keywords: Anti-inflammatory effect; antioxidant effect; DNA damage; nerium oleander.

B urn injuries constitute an important public health problem inducing numerous potentially fatal complications, including shock, anemia, electrolyte imbalances, renal failure, and metabolic disturbances $[1,2]$. Initial responses to thermal injury are denaturation of proteins and destruction of membrane integrity followed by activation of the inflammatory cascade, alterations in the cytokine milieu by rapid release of various cytokines such as tumor necrosis factor alpha $(\mathrm{TNF}-\alpha)$ and interleukins (IL), and secretion of reactive oxygen species (ROS) [2-4]. Oxidative stress emerging

Received: June 14, 2017 Accepted: July 24, 2017 Online: October 19, 2017

Correspondence: Dr. Semra SARDAS. Marmara Universitesi Eczacilık Fakultesi, Tibbiye Caddesi, Haydarpasa, Istanbul, Turkey. Tel: +902163384628 e-mail: ssardas@marmara.edu.tr

(c) Copyright 2015 by Istanbul Northern Anatolian Association of Public Hospitals - Available online at www.kuzeyklinikleri.com 
from tremendous production of ROS is among the most important mechanisms responsible for local and distant pathophysiological events during burn progression [5]. Recent evidences suggest that overproduced ROS triggers lipid, membrane, nucleic acid, and protein damages leading to lipid peroxidation, double-strand DNA breaks (DSB), and single-strand DNA breaks (SSB) along with apoptosis [6-8]. Tissue injury after thermal trauma is associated with elevated ROS levels in addition to effects of activated neutrophils and macrophages creating the need for wound treatment with agents that possess anti-inflammatory or antioxidant [9].

Nitrofurazone [10], silver sulfadiazine [11], and many other remedies have been utilized in burn control and treatment. Phytomedicines to cure burns are brought into the medical forefront during the last decades. Although herbal products are extensively preferred and have become more widely available commercially, modern scientific methods and clinical trials are needed for confirming claims about their therapeutic effects.

Nerium oleander (synonym $N$. indicum Mill) is a well-known evergreen flowering shrub belonging to the Apocynaceae family and numerous activities including antibacterial, antiviral, antifungal, antiinflammatory, and antioxidant $[12,13]$ have been attributed to the presence of alkaloids, flavonoids, phenolics, and glycosides in different parts of the plant [14]. Aloe vera, with its use in dermatological disorders, has an important role in traditional and contemporary medicine because of the occurrence of various biologically active compounds such as flavonoids, saponin, amino acids, vitamins, and minerals [13-15]. On the basis of above-mentioned knowledge, the present study was undertaken to evaluate the ameliorative effect of an Aloe vera-based extract of the $N$. oleander leaf (NAE$8^{\oplus}$ ) on wound healing in a burn induced rat model and to compare the treatment efficacy with that of silver sulfadiazine (SSD), a widely used human medicinal product in burn treatment. For this purpose, rats were randomly allocated to four groups consisting of six rats in each group: i) control, ii) burn alone (burn), iii) burn with topical NAE- $8^{\circledast}$ treatment (burn + NAE $-8^{\circledast}$ ), and iv) burn with topical 1\% SSD treatment (burn+SSD). After completion of the experimental protocol, the skin tissue and blood samples were used for conducting certain biochemical and genotoxicity assays along with histological stainings.

\section{MATERIALS AND METHODS}

\section{Chemicals and reagents}

All chemicals were purchased from Sigma-Aldrich Co. (St Louis, MO, USA), Bio-Optica (Milano, Italy). or E. Merck Co. (Darmstadt, Germany). TNF- $\alpha$ and IL-1 $\beta$ enzyme-linked immunosorbent assay (ELISA) kits were purchased from eBiosience, Bender MedSystems GmbH (Vienna, Austria). Silverdin ${ }^{\oplus}$ (1\% SSD ointment) was bought from Deva Holding Drug Company (Istanbul, Turkey). NAE- $8^{\circledast}$ was obtained from Nerium Biotechnology Inc (San Antonio, TX, USA).

\section{Animals}

Twenty-four Wistar albino rats weighing 200$250 \mathrm{~g}$ were obtained from Marmara University School of Medicine Animal House. The rats were housed in individual cages at a constant temperature $\left(20^{\circ} \mathrm{C} \pm 2^{\circ} \mathrm{C}\right)$ with a $12 \mathrm{~h}$ light-dark cycle and were fed with a standard rat chow and water ad libitum throughout the study. Ethics committee approval for all procedures was received from the Animal Care and Use Committee of Marmara University School of Medicine, Istanbul, Turkey (Approval ID: 63.2015.mar, Approval Date: 6 November 2015).

\section{Experimental design}

The dorsal part of each rat was shaved using an electric razor under brief ether anesthesia. The animals were anesthetized with ketamine ( $80 \mathrm{mg} /$ $\mathrm{kg}$, ip) and xilazyne (10 mg/kg, ip) prior to thermal injury. The shaved back of each animal was immersed in water at $90^{\circ} \mathrm{C}$ for $10 \mathrm{~s}$ to produce a partial-thickness second degree burn injury covering $30 \%$ of the total body surface area, whereas animals in the control group were immersed in $25^{\circ} \mathrm{C}$ 
water and resuscitation was achieved by subcutaneous injection of $10 \mathrm{ml} / \mathrm{kg}$ physiological saline. All groups received the respective topical application of NAE $-8^{\circledast}, 1 \% \mathrm{SSD}$, or physiological saline at a dose of $2 \mathrm{ml} / \mathrm{kg} /$ day; $2 \mathrm{~g} / \mathrm{kg} /$ day, or $2 \mathrm{ml} / \mathrm{kg} /$ day, respectively, twice a day for 14 consecutive days. At the end of the experiment, animals were euthanized by decapitation followed by the collection of trunk blood used for TNF- $\alpha$, IL-1 $1 \beta$, and $\% \mathrm{DNA}_{\mathrm{T}}$ measurement. Skin tissue samples were kept at $-20^{\circ} \mathrm{C}$ for biochemical assays, whereas the samples for histological examination were stored in $10 \%$ neutral buffered formalin at room temperature $\left(25^{\circ} \mathrm{C}\right)$.

\section{Malondialdehyde and glutathione levels}

Skin tissue samples were homogenized (w/v 10\%) in $10 \%$ trichloroacetic acid and centrifuged at $3000 \mathrm{rpm}$ at $4^{\circ} \mathrm{C}$ for $15 \mathrm{~min}$. The supernatants obtained were used for determining malondialdehyde (MDA) and glutathione (GSH) levels. MDA levels were examined by monitoring the reaction between same volume of trichloroacetic acid and supernatant at $100^{\circ} \mathrm{C}$ [16]. Absorbance was measured at $532 \mathrm{~nm}$, and the results are expressed as nmol MDA/g tissue. GSH levels were determined using a modification of the Ellman procedure [17] by measuring the absorbance at $412 \mathrm{~nm}$, and the results are expressed as $\mu \mathrm{mol} \mathrm{GSH} / \mathrm{g}$ tissue.

\section{Myeloperoxidase activity}

Myeloperoxidase (MPO) activity was measured via a $\mathrm{MPO}$-dependent reaction of o-dianisidine and hydrogen peroxide at $460 \mathrm{~nm}$ using a similar procedure as reported by Hillegass et al. [18] and the results are expressed as $\mathrm{U} / \mathrm{g}$ tissue.

\section{Cytokine assays}

Serum TNF- $\alpha$ and IL- $1 \beta$ levels were assayed in duplicates using the commercial ELISA kits, and the results are expressed as $\mathrm{pg} / \mathrm{ml}$.

\section{Single-cell gel electrophoresis (Comet assay)}

The alkaline comet assay was performed using on a modified procedure of that used by Singh et al. [19]. Each slide was blindly viewed by one slide reader under a fluorescence microscope (Olympus-BX51, Olympus Corporation, Tokyo, Japan) equipped with an excitation filter of $546 \mathrm{~nm}$ and a barrier filter of $590 \mathrm{~nm}$. The percentage of DNA in the tail (\% $\left.\mathrm{DNA}_{\mathrm{T}}\right)$ was taken as a measure of DNA-break frequency by scoring 100 cells per sample using image analysis software $B A B$ Bs200Pro Image Processing and Analysis System of BAB Muh., Ankara, Turkey).

\section{Histological examination}

The excised skin stored in 10\% neutral buffered formalin solution was dehydrated in ascending alcohol series, cleared in xylene, and embedded in paraffin. Paraffin sections ( $3 \mu \mathrm{m}$ thick) were cut, deparaffinized, and stained with hematoxylin and eosin (H\&E) or Gomori's one step trichrome. All sections were blindly examined and photographed under a light microscope (Olympus-CX41RF, Olympus Corporation, Tokyo, Japan) by an experienced histologist. Congestion, necrosis, inflammatory cell infiltration, fibroblast proliferation, epithelization, and angiogenesis were scored semiquantitatively and ranked as none, slight, and moderate, as reported by Kwansang et al. [20].

\section{Statistics}

Statistical analyses were performed using the GraphPad InStat (GraphPad Software, San Diego, CA) program. All results are provided as means \pm standard error of mean; groups of data were compared using one-way analysis of variance (one-way ANOVA) followed by Tukey's multiple comparison tests. Values of $\mathrm{p}<0.05$ were considered as significant.

\section{RESULTS}

The effect of NAE- $8^{\oplus}$ on investigated parameters in each group is presented in Table 1 . NAE- $8^{\circledR}$ treatment significantly reduced the elevated MDA level in the burn $+\mathrm{NAE}-8^{\varpi}$ group $(47.07 \pm 12.71 \mathrm{nmol} / \mathrm{g}$; $\mathrm{p}<0.001)$ compared with that in the burn group 
TfBLE 1. Effect of NAE-8® on MPO activity and MDA, GSH, IL-1 $\beta$, TNF- $a$, and \%DNAT levels

\begin{tabular}{|c|c|c|c|c|c|c|}
\hline Group & $\begin{array}{c}\text { MDA } \\
\text { (nmol/g tissue) }\end{array}$ & $\begin{array}{c}\text { GSH } \\
(\mu \mathrm{mol} / \mathrm{g} \text { tissue })\end{array}$ & $\begin{array}{c}\text { MPO } \\
\text { (U/g tissue) }\end{array}$ & $\begin{array}{l}\text { TNF-a } \\
(\mathrm{pg} / \mathrm{mL})\end{array}$ & $\begin{array}{l}\text { IL1- } \beta \\
(\mathrm{pg} / \mathrm{mL})\end{array}$ & $\% \mathrm{DNA}_{\mathrm{T}}$ \\
\hline i) Control & $15.23 \pm 1.74$ & $3.29 \pm 0.26$ & $0.77 \pm 0.12$ & $25.33 \pm 2.94$ & $30.17 \pm 3.95$ & $25.42 \pm 0.25$ \\
\hline ii) Burn & $185.38 \pm 17.55^{* * *}$ & $1.78 \pm 0.18^{* * *}$ & $3.94 \pm 0.71 * * *$ & $45.17 \pm 3.72 * * *$ & $108.25 \pm 16.89 * * *$ & $30.25 \pm 0.73^{* * *}$ \\
\hline iii) Burn+NAE- $8 ®$ & $47.07 \pm 12.71^{+++}$ & $3.19 \pm 0.25^{+++}$ & $1.58 \pm 0.08^{++}$ & $30.00 \pm 2.85^{++}$ & $49.50 \pm 4.46^{+++}$ & $27.91 \pm 0.28^{++}$ \\
\hline iv) Burn+SSD & $135.49 \pm 22.83$ & $2.74 \pm 0.17^{+}$ & $2.81 \pm 0.61$ & $30.17 \pm 1.30^{++}$ & $29.50 \pm 2.40^{+++}$ & $25.28 \pm 0.19^{+++}$ \\
\hline
\end{tabular}

$* * * p<0.001$ compared to with the control group, $+p<0.05,++p<0.01$ and $+++p<0.001$ compared to with the burn group ( $n=6$ rats per/group). Data are expressed as mean \pm standard error of mean.

GSH: Glutathione; IL-1ß: Interleukin-1 $\beta$; MDA: Malondialdehyde; MPO: Myeloperoxidase; NAE-8®: Aloe vera-based extract of Nerium oleander; TNF-a: Tumor necrosis factor; SSD: $1 \%$ silver sulphadiazinesulfadiazine; \%DNAT: The percentages of DNA in tail.
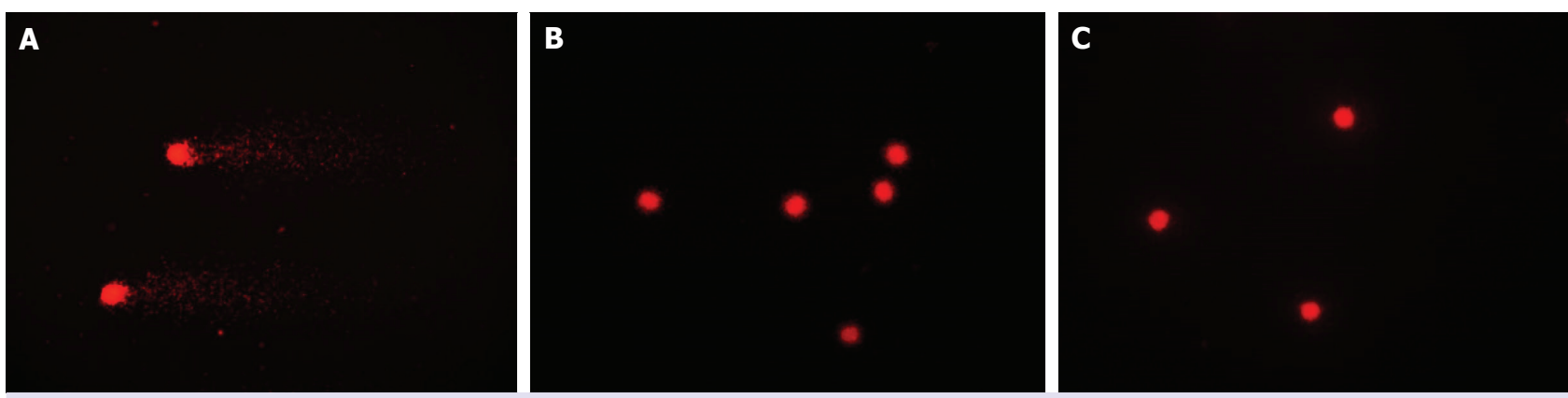

FIGURE 1. Images of comets from burn injury $(A), N A E-8 \otimes$ treatment after burn injury (B), and SSD treatment after burn injury (C).

$(185.38 \pm 17.55 \mathrm{nmol} / \mathrm{g})$. Compared with the burn group, similar positive effects were also observed for skin GSH levels in the burn+NAE- $8^{\circledast}(\mathrm{p}<0.001)$ and burn+SSD groups $(\mathrm{p}<0.05)$.

The significant elevation in MPO activity in the burn group $(3.94 \pm 0.71 \mathrm{U} / g ; \mathrm{p}<0.001)$ compared with that in the control group $(0.77 \pm 0.12$ $\mathrm{U} / \mathrm{g})$ was abolished by NAE- $8^{\otimes}(1.58 \pm 0.08 \mathrm{U} / \mathrm{g})$ and SSD treatments $(2.81 \pm 0.61 \mathrm{U} / \mathrm{g})$, and only the burn + NAE $-8^{\otimes}$ group showed a statistically significant difference compared with the burn group $(\mathrm{p}<0.01)$.

Serum TNF- $\alpha$ and IL- $1 \beta$ levels were reduced by both NAE- $8^{\circledR}$ and SSD treatment in the burn $+\mathrm{NAE}-8^{\circledast}$ and burn $+\mathrm{SSD}$ groups, respectively, compared with those in the burn group, as demonstrated in Table 1.

A significant $(p<0.001)$ increase the mean $\% \mathrm{DNA}_{\mathrm{T}}$ was observed in the burn group $(30.25 \pm 0.73)$ compared with that in the control group $(25.42 \pm 0.25)$. Treatment with $\mathrm{NAE}-8^{\circledR}$ and SSD significantly reduced the increase in the mean $\% \mathrm{DNA}_{\mathrm{T}}$ triggered by burn injury, and the images of comets are shown in Figure 1.

Histological analysis revealed that skin sections from the control group showed regular tissue characteristics with intact sebaceous glands, hair follicles, and dermal collagen (Fig. 2A, E). Burn trauma led to severe degeneration with epidermal detachment, scabs formation of the necrotic tissue remnants, va- 

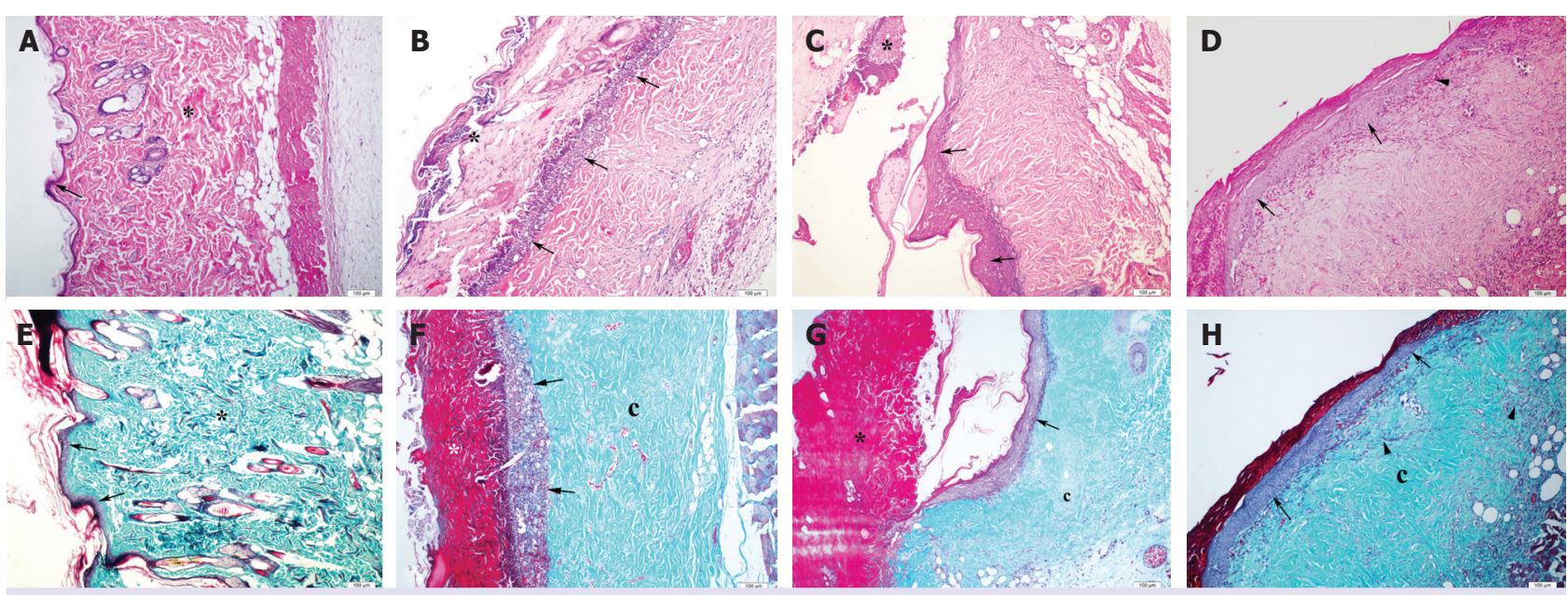

FIGURE2. Histological evaluation of wound skin sections stained with hematoxylin and eosin (H\&E) and Gomori's one step trichrome ( $\times 100)$. Regular tissue with epidermis (arrow) and dermis (asterics) in the control group (A, E). Necrotic area/ crust (asterics), inflammatory cell infiltration (arrow), and collagen (c) in the burn group (B, F). Necrotic area/crust (asterics), re-epithelization (arrow), and collagen (c) in the burn+SSD group (C, G). Re-epithelization (arrow) and angiogenesis (arrowhead) in the burn + NAE-8® group (D). Re-epithelization (arrow), collagen (c), and fibroblast proliferation (arrowhead) in the burn + NAE-8® group $(H)$.

TABLE2. Histological scores in burn wounds of treated groups

\begin{tabular}{lccc} 
Group $(\mathrm{n}=6)$ & Burn & Burn+NAE-8® & Burn+SSD \\
\hline Congestion & ++ & + & ++ \\
Necrosis & +++ & ++ & ++ \\
Inflammatory cell infiltration & +++ & ++ & ++ \\
Fibroblast proliferation & ++ & +++ & +++ \\
Epithelization & + & ++ & ++ \\
Angiogenesis & ++ & ++ & ++
\end{tabular}

-: none; +: slight; ++: moderate; +++: marked.

NAE-8®: Aloe vera-based extract of Nerium oleander; SSD: $1 \%$ silver sulfadiazine.

socongestion, and edema. There were extensive inflammatory cell infiltrations and no hair follicles or sebaceous glands in the dermis, as demonstrated in Figure 2B, F.

The burn $+\mathrm{NAE}-8^{\circledast}$ and burn $+\mathrm{SSD}$ groups revealed remarkable healing with decreases in inflammatory cells and necrosis along with increases in fibroblast proliferation, angiogenesis, and re-epithe- lization compared with that in the burn group, as observed using the H\&E-stained skin sections (Table 2, Figure $2 \mathrm{C}, \mathrm{D}$ vs $\mathrm{B}$ ).

Decreased inflammatory cells in the burn + SSD and burn $+\mathrm{NAE}-8^{\oplus}$ groups were also observable with the Gomori's one step trichrome stain (Figure $2 \mathrm{G}, \mathrm{H})$. SSD treatment triggered the re-epithelization process and reduced necrosis in the burn $+\mathrm{SSD}$ group compared with that in the burn group. Light microscopic findings revealed that NAE- $8^{\circledR}$ and SSD treatment have shown similar healing processes with clearly developed epidermis and regular collagen levels.

\section{DISCUSSION}

Burn injury produces a burst of free radicals that interact with various biomolecules, leading to the destruction of cellular components, inflammatory reactions, increased oxidative stress in the cells, and delay in healing $[21,22]$. The effects of antioxidant treatment on burn injuries have been comprehensively studied because antioxidants prevent the oxidation of biomolecules by eliminating overproduced ROS, removing inflammation products, and fa- 
cilitating a quicker wound healing process $[22,23]$. Lipid peroxidation, which is considered to be one of the most deleterious events occurring secondary to burn injury with excessive expression of MDA [24], has been seen in the burn group along with depletion of GSH stores [25]. NAE- $8^{\varpi}$ treatment reversed these parameters, indicating that NAE $-8^{\otimes}$ reduces lipid peroxidation and supports the maintenance of cellular integrity as a potent antioxidant. Similarly, Benson et al. [13] recently showed the protective effect of NAE- $8^{\circledast}$ on intracellular reduced GSH stores in a study performed using human primary dermal fibroblasts. Various studies have also demonstrated the amendatory effect of Nerium on GSH and MDA because of its beneficial effect against lipid peroxidation [26, 27]. Consequently, the findings of the present study supported the anticipated antioxidant activity of NAE $-8^{\circledast}$ probably because of the contribution of well-known effects of each ingredient.

Severe burn injury represents a pathophysiological condition in which activated neutrophils and macrophages produce increased levels of proinflammatory mediators, such as TNF- $\alpha$ and IL- $1 \beta$, contributing to cellular injury [25-28]. The traditionally known anti-inflammatory activity of $N$. oleander [27] has recently been confirmed by Dey and Chaudhuri in a study with murine splenic lymphocytes [29]. Besides, the anti-inflammatory activity of NAE $-8^{\circledast}$ accompanying the induction of certain $\mathrm{cy}$ tokines in dermal fibroblasts of relevance to wound healing was demonstrated by recent reports $[13,30]$. Our findings, which are consistent with those of previous reports, accentuated the significant downregulation of burn-related increases in TNF- $\alpha$ and IL$1 \beta$ expressions by NAE $-8^{\circledast}$ treatment. In addition to abnormal cytokine levels, burn-related significant increases in MPO activity was reduced by NAE $-8^{\circledR}$ treatment, referring to its inhibitory effect of tissue neutrophil infiltration.

DNA damage including SSB, DSB, apurinic/ apyrimidinic site, and strand fragmentation can occur when the balance between endogenous oxidants and antioxidant defenses is impaired because of burn injury [31]. Furthermore, the relation between DNA strand breaks and heat has been previously investigated even though the underlying mechanism has not yet been clarified [32-34]. The evaluation of heat-induced production of DSBs was performed by comet assay [35]. The present study is, to the best of our knowledge, the first in vivo study examining combined effects of $N$. oleander and Aloe vera on thermal injury-induced genotoxicity by comet assay. DNA damage was escalated by burn injury as evidenced by the significantly increased $\% \mathrm{DNA}_{\mathrm{T}}$ in the burn group. This elevation was reduced by NAE- $8^{\circ}$ treatment, which might be considered as a sign of its DNA repair capacity.

Regeneration of the epidermis, reduction in infiltrated cell levels, the role of fibroblasts and endothelial cells in repairing the dermis, and reinforcement of capillary growth and collagen development was previously underlined [36]. A study by Rout et al. [37] revealed that $N$. oleander extract has a remarkable wound healing activity in rats, most probably due to its antimicrobial and antioxidant activities. The enhancing effect of Aloe vera to collagen levels providing strength and integrity to the tissue matrix and playing an important role in hemeostasis along with epithelialization were also previously reported $[15$, 38]. In accordance with the prior studies, the present study revealed clearly developed epithelization after NAE $-8^{\circledast}$ treatment along with irrefutable reductions in the extent of necrosis and inflammatory cell infiltration. Furthermore, NAE- $8^{\circledast}$ treatment strongly induced migration of fibroblasts which produce matrix proteins, fibronectin, proteoglycan, hyaluronan, and collagens for wound repair [20].

In conclusion, analyzed data presented here with enhanced antioxidant and anti-inflammatory effects, DNA repair capacity, and histological findings suggest that $\mathrm{NAE}-\mathrm{8}^{\odot}$ is a new therapeutic remedy in skin care to manage burn wound, which offers a scientific reinforcement for future studies.

Conflict of Interest: None declared.

Financial Disclosure: This study was financially supported by the Commission of Scientific Investigations Projects (BAPKO) of Marmara University (Project No: SAG-C-DRP-110316-0078).

Authorship contributions: Concept: S.S., S.G.A.; Design: S.S., S.G.A.; Supervision: S.S.; Materials: S.G.A, S.A., N.O., M.Y.; Data collection \&/or processing: S.G.A, S.A., N.O., M.Y.; Analysis \&/or interpretation: S.G.A, S.A., N.O., M.Y.; Literature search: S.G.A.; Writing: S.G.A.; Critical review: S.S. 


\section{REFERENCES}

1. Priya KS, Gnanamani A, Radhakrishnan N, Babu M. Healing potential of Datura alba on burn wounds in albino rats. J Ethnopharmacol 2002;83:193-9. [CrossRef]

2. Evers LH, Bhavsar D, Mailander P. The biology of burn injury. Exp Dermatol 2010;19:777-83. [CrossRef]

3. Summer GJ, Romero-Sandoval EA, Bogen O, Dina OA, Khasar SG, Levine JD. Proinflammatory cytokines mediating burn-injury pain. Pain 2008;135:98-107. [CrossRef]

4. Orman MA, Nguyen TT, Ierapetritou MG, Berthiaume F, Androulakis IP. Comparison of the cytokine and chemokine dynamics of the early inflammatory response in models of burn injury and infection. Cytokine 2011;55:362-71. [CrossRef]

5. da Silva NT, Quintana HT, Bortolin JA, Ribeiro DA, de Oliveira F. Burn injury induces skeletal muscle degeneration, inflammatory host response, and oxidative stress in wistar rats. J Burn Care Res 2015;36:428-33. [CrossRef]

6. Fujita R, Tanaka Y, Saihara Y, Yamakita M, Ando D, Koyama K. Effect of molecular hydrogen saturated alkaline electrolyzed water on disuse muscle atrophy in gastrocnemius muscle. J Physiol Anthropol 2011;30:195-201. [CrossRef]

7. Prisăcaru AI, Andrițoiu CV, Andriescu C, Hăvârneanu EC, Popa M, Motoc AG, et al. Evaluation of the wound-healing effect of a novel Hypericum perforatum ointment in skin injury. Rom J Morphol Embryol 2013;54:1053-9.

8. Kaymak C, Kadioglu E, Ozcagli E, Osmanoglu G, Izdes S, Agalar C, et al. Oxidative DNA damage and total antioxidant status in rats during experimental gram-negative sepsis. Hum Exp Toxicol 2008;27:485-91. [CrossRef]

9. Sehirli O, Sener E, Sener G, Cetinel S, Erzik C, Yeğen BC. Ghrelin improves burn-induced multiple organ injury by depressing neutrophil infiltration and the release of pro-inflammatory cytokines. Peptides 2008;29:1231-40. [CrossRef]

10. Stensballe J, Tvede M, Looms D, Lippert FK, Dahl B, Tønnesen $\mathrm{E}, \mathrm{Rasmussen}$ LS. Infection risk with nitrofurazone-impregnated urinary catheters in trauma patients: a randomized trial. Ann Int Med 2007;147:285-93. [CrossRef]

11. Thakkar V, Korat V, Baldaniya L, Gohel M, Gandhi T, Patel N. Development and characterization of novel hydrogel containing antimicrobial drug for treatment of burns. Int J Pharm Investig 2016;6:158-68. [CrossRef]

12. Dey P, Chaudhuri TK. Pharmacological aspects of Nerium indicum Mill: A comprehensive review. Pharmacogn Rev 2014;8:156-62. [CrossRef]

13. Benson KF, Newman RA, Jensen GS. Antioxidant, anti-inflammatory, anti-apoptotic, and skin regenerative properties of an Aloe vera-based extract of Nerium oleander leaves (NAE- $8^{\circ}$ ). Clin Cosmet Investig Dermatol 2015;8:239-48.

14. Dey P, Roy S, Chaudhuri TK. A quantitative assessment of bioactive phytochemicals of Nerium indicum: An ethnopharmacological herb. International Journal of Research in Pharmaceutical Sciences 2012;3:579-87.
15. Farzadinia P, Jofreh N, Khatamsaz S, Movahed A, Akbarzadeh S, Mohammadi M, et al. Anti-inflammatory and wound healing activities of Aloe vera, honey and milk ointment on seconddegree burns in rats. Int J Low Extrem Wounds 2016;15:2417. [CrossRef]

16. Casini A, Ferrali M, Pompella AS, Maellaro E, Comporti M. Lipid peroxidation and cellular damage in extrahepatic tissues of bromobenzene intoxicated mice. Am J Pathol 1986;123:520-31.

17. Aykac G, Uysal M, Yalcin AS, Kocak-Toker N, Sivas A, Oz H. The effect of chronic ethanol ingestion on hepatic lipid peroxide, glutathione peroxidase and glutathione transferase in rat. Toxicology 1985;46:71-6. [CrossRef]

18. Hillegass LM, Griswold DE, Brickson B, Albrightson-Winslow C. Assessment of myeloperoxidase activity in whole rat kidney. J Pharmacol Methods 1990;24:285-95. [CrossRef]

19. Singh NP, McCoy MT, Tice RR, Schneider EL. A simple technique for quantitation of low levels of DNA damage in individual cells. Exp Cell Res 1988;175:184-91. [CrossRef]

20. Kwansang J, Itthipanichpong C, Limpanasithikul W. Evaluation of wound healing activity of Thunbergia laurifolia supercritical carbon dioxide extract in rats with second-degree burn wounds. J Adv Pharm Technol Res 2015;6:103-7. [CrossRef]

21. Dissemond J, Goos M, Wagner SN. The role of oxidative stress in the pathogenesis and therapy of chronic wound. Hautarzt 2002;53:718-23. [CrossRef]

22. Gangwar M, Gautam MK, Ghildiyal S, Nath G, Goel RK. Mallotus philippinensis Muell. Arg fruit glandular hairs extract promotes wound healing on different wound model in rats. BMC Complement Altern Med 2015;15:123. [CrossRef]

23. Toklu HZ, Tunali-Akbay T, Erkanli G, Yüksel M, Ercan F, Sener G. Silymarin, the antioxidant component of Silybum marianum,protects against burn-induced oxidative skin injury. Burns 2007;33:908-16. [CrossRef]

24. Wang CZ, El Ayadi A, Goswamy J, Finnerty CC, Mifflin R, Sousse L, et al. Topically applied metal chelator reduces thermal injury progression in a rat model of brass comb burn. Burns 2015;41:1775-87. [CrossRef]

25. Horton JW. Free radicals and lipid peroxidation mediated injury in burn trauma: the role of antioxidant therapy. Toxicology 2003;189:75-88. [CrossRef]

26. Gayathri V, Ananthi S, Chandronitha C, Ramakrishnan G, Lakshmi-Sundaram R, Vasanthi HR. Cardioprotective effect of Nerium oleander flower against isoproterenol induced myocardial oxidative stress in experimental rats. J Cardiovasc Pharmacol Ther 2011;16:96-104. [CrossRef]

27. Dey P, Dutta S, Sarkar MP, Chaudhuri TK. Assessment of hepatoprotective potential of $\mathrm{N}$. indicum leaf on haloalkane xenobiotic induced hepatic injury in Swiss albino mice. Chem Biol Interact 2015;235:37-46. [CrossRef]

28. Molloy RG, O'Riordain M, Holtzeimer R, Nestor M, Collins $\mathrm{K}$, Mannick JA, et al. Mechanisms of increased tumor necrosis factor production after thermal injury. Altered sensitivity to PG2 and immune modulation by indomethacin. Journal of Immunol- 
ogy 1993;151:2142-49.

29. Dey P, Chaudhuri TK. Immunomodulatory activity of Nerium indicum through inhibition of nitric oxide and cyclooxygenase activity and modulation of TH1/TH2 cytokine balance in murine splenic lymphocytes. Cytotechnology 2016;68:749-61.

30. Benson KF, Newman RA, Jensen GS. Water-soluble egg membrane enhances the immunoactivating properties of an Aloe vera-based extract of Nerium oleander leaves. Clin Cosmet Investig Dermatol 2016;9:393-403. [CrossRef]

31. Valavanidis A, Vlachogianni T, Fiotakis C. 8-hydroxy-2' -deoxyguanosine (8-OHdG): A Critical Biomarker of Oxidative Stress and Carcinogenesis. J Environ Sci Health C 2009;27;120-39.

32. Purschke M, Laubach HJ, Anderson RR, Manstein D. Thermal injury causes DNA damage and lethality in unheated surrounding cells: active thermal bystander effect. J Invest Dermatol 2010;130:86-92. [CrossRef]

33. Dikomey E, Franzke J. Effect of heat on induction and repair of
DNA strand breaks in X-irradiated CHO cells. Int J Radiat Biol 1992;61:221-33. [CrossRef]

34. Dahm-Daphi J, Brammer I, Dikomey E. Heat effects on the repair of DNA double-strand breaks in $\mathrm{CHO}$ cells. Int J Radiat Biol 1997;72:171-9. [CrossRef]

35. Takahashi A, Ohnishi T. Does gammaH2AX foci formation depend on the presence of DNA double strand breaks? Cancer Lett 2005;229:171-9. [CrossRef]

36. Guo S, Dipietro LA. Factors affecting wound healing. J Den Res 2010;89:219-29. [CrossRef]

37. Rout SK, Kar DM, Maharana L. Evaluation of antimicrobial, antioxidant and wound healing activity of different fractions of methanolic extract of Nerium oleander Linn. Int J Drug Dev \& Res 2014;6:241-51.

38. Chithra P, Sajithlal GB, Chandrakasan G. Influence of aloe vera on the healing of dermal wounds in diabetic rats. J Ethnopharmacol 1998;59:195-201. [CrossRef] 